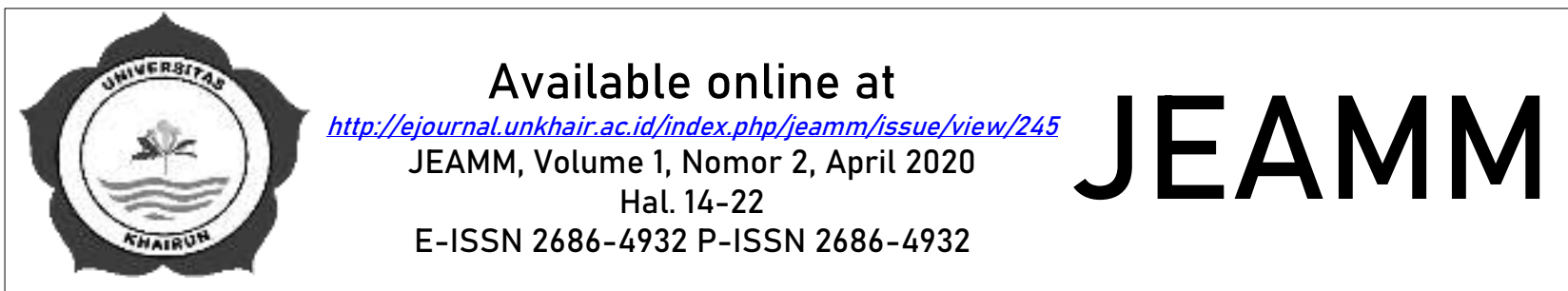

\title{
PENGARUH PERILAKU BELAJAR, KECERDASAN EMOSIONAL, DAN TINGKAT PEMAHAMAN AKUNTANSI TERHADAP STRES BELAJAR MAHASISWA AKUNTANSI
}

\author{
${ }^{1}$ Ilfan Bereki ${ }^{2}$ Widya Murdhanata Saputra \\ Fakultas Ekonomi Universitas Pasifik \\ 1ilfanbereki@gmail.com
}

Dikirim, 5 Maret 2020

Revisi, 12 Maret 2020

Diterima, 25 Maret 2020

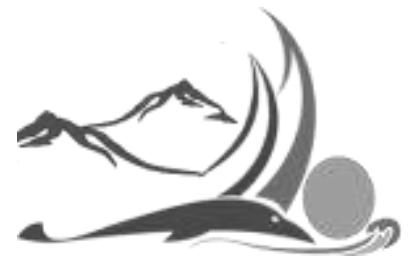

Jurnal Ekonomi, Akuntansi dan Manajemen

Multiparadigma

Volume 1, Nomor 2,

April 2020

\section{ABSTRAK}

Penelitian ini bertujuan untuk menganalisis pengaruh Perilaku belajar, Kecedasan Emosional dan Tingkat pemahaman akuntansi terhadap Stres belajar mahasiswa akuntansi Fakultas Ekonomi Program Studi Akuntansi Universitas Pasifik Morotai. Populasi dalam penelitian ini adalah mahasiswa akuntansi pada Fakultas Ekonomi Universitas Pasifik. Jenis data yang digunakan adalah data primer dengan metode pengambilan data menggunakan kuesioner. Metode pengambilan sampel menggunakan teknik purposive sampling. Hasil penelitian menunjukkan secara parsial, seluruh variabel independen yakni perilaku belajar, kecerdasan emosional, tingkat pemahaman akuntansi pengaruh positif terhadap variable Stres Belajar mahasiswa akuntansi.

Kata kunci: Perilaku Belajar, Kecerdasan Emosional, Tingkat Pemahaman Akuntansi. Stres Belajar

\section{ABSTRCT}

This study aims to analyze the effect of learning behavior, emotional anxiety and the level of understanding of accounting towards accounting student-learning stress in the Faculty of Economics Universitas Pasifik Morotai. Population in this study is accounting students at the Faculty of Economics, Pacific University. The type of data used is primary data with a data collection method using a questionnaire. The sampling method uses purposive sampling technique. The results showed partially, all independent variables namely learning behavior, emotional intelligence, the level of understanding of accounting a positive influence on the variable of Learning Stress of accounting students.

Keywords: Learning Behavior, Emotional Intelligence, Level of Understanding of Accounting, Learning Stress 


\section{PENDAHULUAN}

Dewasa ini kita dihadapkan pada masalah-masalah kehidupan yang semakin kompleks. Terutama kita yang hidup di daerah perkotaan yang sangat rentan pada teknologi, komunikasi, dan perkembangan sosial ekonomi. Perkembangan semua itu tidak selamanya membuat perubahan kehidupan kita menuju ke perbaikan, hal itu tergantung pada bagaimana kita menyikapi dan memanfaatkan perubahan tersebut.

Beberapa penelitian menunjukkan bahwa perubahan yang selama ini kita rasakan telah merubah pola kehidupan generasi kita menjadi pribadi yang individual, materialis, dan cenderung kapitalis. Bahkan beberapa penelitian menunjukkan bahwa tidak semua mereka yang memiliki jabatan dan titel kesarjanaan yang tinggi memiliki kecerdasan emosional yang tinggi. Kecerdasan emosional adalah kemampuan seseorang mengendalikan emosinya saat menghadapi situasi yang menyenangkan maupun menyakitkan (Hidayat dalam Aziza \& RM, 2006).

Keberhasilan hidup lebih banyak ditentukan oleh kecerdasan emosional, yaitu aspek-aspek yang berkaitan dengan kepribadian, yang terdiri dari empat unsur pokok, yaitu: Pertama, kemampuan seseorang memahami dan memotivasi potensi dirinya; Kedua, memiliki rasa empati yang tinggi terhadap orang lain; Ketiga, senang bahkan mendorong anak buah sukses, tanpa merasa dirinya terancam; Keempat, asertif yaitu terampil menyampaikan pikiran dan perasaan dengan baik, lugas, dan jelas tanpa harus membuat orang lain tersinggung (Goleman dalam Aziza \& RM, 2006)). Kuliah dan pekerjaan merupakan dua hal yang saling berkaitan. Banyak mahasiswa menempuh jalur kuliah untuk mendapatkan gelar kesarjanaan dan pada akhirnya hal tersebut digunakan untuk memenuhi salah satu syarat untuk dapat bekerja di suatu perusahaan. Berdasarkan beberapa pengalaman penulis, banyak pencari kerja yang mengeluh karena banyak mahasiswa yang memiliki Indeks Prestasi Kumulatif (IPK) yang tinggi tetapi kepribadiannya kurang. Salah satu aspek kepribadian dapat dilihat dari kecerdasan emosionalnya. Fakta-fakta inilah yang membuat penulis tertarik untuk meneliti kecerdasan emosional mahasiswa akuntansi dalam hubungannya dengan pemahaman mata kuliah akuntansi. Pemahaman mata kuliah akuntansi yang baik akan mempengaruhi kemampuan mahasiswa akuntansi saat terjun ke dunia kerja.

Stres tidak dapat dipisahkan dari setiap aspek kehidupan. Stres dapat dialami oleh siapa saja dalam bentuk tertentu, dalam kadar berat ringan yang berbeda dan dalam jangka panjang-pendek yang tidak sama, pernah atau akan mengalaminya dan tidak seorang pun bisa terhindar dari padanya dan memiliki implikasi negatif jika berakumulasi dalam kehidupan individu tanpa solusi yang tepat. Akumulasi stres merupakan akibat dari ketidakmampuan individu dalam mengatasi dan mengendalikan stresnya (Crampton, Hodge, Mishra, \& Price, 1995).

Mahasiswa dalam kegiatannya juga tidak terlepas dari stres. Stresor atau penyebab stres pada mahasiswa dapat bersumber dari kehidupan akademiknya, terutama dari tuntutan eksternal dan tuntutan dari harapannya sendiri. Tuntutan eksternal dapat bersumber dari tugas-tugas kuliah, beban pelajaran, tuntutan orang tua untuk berhasil di kuliahnya, dan penyesuaian sosial di lingkungan kampusnya (Umasugi, Buamonabot, \& Anfas, 2015; Anfas, Buamonabot, Umasugi, \& Sudarwo, 2018; Fahri, Syahrain, \& Buamonabot, 2020). Tuntutan ini juga termasuk kompetensi perkuliahan dan meningkatnya kompleksitas materi perkuliahan yang semakin lama semakin sulit. Tuntutan dari harapan mahasiswa dapat bersumber dari kemampuan mahasiswa dalam mengikuti pelajaran (Kariv \& Heiman, 2005)

Stres yang tidak mampu dikendalikan dan diatasi oleh individu akan memunculkan dampak negatif. Pada mahasiswa, dampak negatif secara kognitif antara lain sulit berkonsentrasi, sulit mengingat pelajaran, dan sulit memahami pelajaran. Dampak negatif 
secara emosional antara lain sulit memotivasi diri, munculnya perasaan cemas, sedih, kemarahan, frustrasi, dan efek negatif lainnya. Dampak negatif secara fisiologis antara lain gangguan kesehatan, daya tahan tubuh yang menurun terhadap penyakit, sering pusing, badan terasa lesu, lemah, dan insomnia (kurang tidur). Dampak perilaku yang muncul antara lain menunda-nunda penyelesaian tugas kuliah, malas kuliah, penyalahgunaan obat dan alkohol terlibat dalam kegiatan mencari kesenangan yang berlebih-lebihan serta berisiko tinggi (Kariv \& Heiman, 2005). Besarnya dampak negatif stres yang terjadi pada mahasiswa tersebut menuntut untuk mencari tau hal-hal yang dapat mempengaruhi terjadinya stres pada mahasiswa dalam hal ini mahasiswa akuntansi. Berbagai penelitian pernah dilakukan untuk meneliti stres yang terjadi pada mahasiswa, salah satunya penelitian yang dilakukan oleh (Marita, Suryaningsum, \& Shaalih, 2008) yang meneliti mengenai pengaruh perilaku belajar dan kecerdasan emosional terhadap stres kuliah mahasiswa akuntansi, dari hasil penelitian tersebut didapati bahwa perilaku belajar dan kecerdasan emosional berpengaruh negatif terhadap terjadinya stres pada mahasiswa akuntansi.

Perilaku belajar seorang mahasiswa sangat berpengaruh terhadap kelangsungan perkuliahannya. Belajar yang efisien dapat dicapai apabila menggunakan strategi yang tepat, yakni adanya pengaturan waktu yang baik dalam mengikuti perkuliahan, belajar di rumah, belajar berkelompok ataupun untuk mengikuti ujian. Perilaku belajar yang baik dapat terwujud apabila mahasiswa sadar akan tanggung jawab mereka sebagai mahasiswa sehingga mereka dapat membagi waktu mereka dengan baik antara belajar dengan kegiatan di luar belajar. (Roestiah dalam Rachmi, 2011). Selain perilaku belajar, kecerdasan emosional seseorang sangat mempengaruhi kehidupan tidak hanya berpengaruh terhadap terjadinya stres. Banyak contoh disekitar kita membuktikan bahwa orang yang memiliki kecerdasan otak saja belum tentu sukses berkiprah di dunia pekerjaan. Kemampuan akademik bawaan, nilai rapor, dan prediksi kelulusan pendidikan tinggi tidak memprediksi seberapa baik kinerja seseorang setelah bekerja atau seberapa tinggi sukses yang dicapainya dalam hidup. Sebaliknya ia menyatakan bahwa seperangkat kecakapan khusus seperti empati, disiplin diri, dan inisiatif mampu membedakan orang sukses dari mereka yang berprestasi biasabiasa saja, selain kecerdasan akal yang dapat mempengaruhi keberhasilan orang dalam bekerja (Goleman dalam Rachmi, 2011).

Risharliea, (2011) menyatakan bahwa kecerdasan spritual melampaui keyakinan dan pengalaman manusia, serta merupakan bagian terdalam dan terpenting dari manusia. Kecerdasan spiritual dibutuhkan untuk memfungsikan kecerdasan emosional dan kecerdasan intelektual secara efektif. Disisi lain (Nugroho 2004 dalam Rachmi, 2011) menyatakan bahwa pembelajaran yang hanya berpusat pada kecerdasan intelektual tanpa menyeimbangkan sisi spiritual akan menghasilkan generasi yang mudah putus asa, depresi, suka tawuran bahkan menggunakan obat-obat terlarang, sehingga banyak mahasiswa yang kurang menyadari tugasnya sebagai seorang mahasiswa yaitu tugas belajar. Kurangnya kecerdasan spiritual dalam diri seorang mahasiswa akan mengakibatkan mahasiswa kurang termotivasi untuk belajar dan sulit untuk berkonsentrasi, sehingga mahasiswa akan sulit untuk memahami suatu mata kuliah.

Sementara itu, mereka yang hanya mengejar prestasi berupa nilai atau angka dan mengabaikan nilai spiritual, akan menghalalkan segala cara untuk mendapakan nilai yang bagus, mereka cenderung untuk bersikap tidak jujur seperti menyontek pada saat ujian. Oleh karena itu, kecerdasan spiritual mampu mendorong mahasiswa mencapai keberhasilan dalam belajarnya karena kecerdasan spiritual merupakan dasar untuk mendorong berfungsinya secara efektif kecerdasan intelektual (IQ) dan kecerdasan emosional (EQ). Berdasarkan uraian di atas, penulis bermaksud mengadakan penelitian yang meneliti perilaku belajar, kecerdasan emosional dan kecerdasan spiritual. 
Sebagai variabel yang mempengaruhi terjadinya stres kuliah. Penelitian ini berbeda dari penelitian sebelumnya, di mana pada penelitian Marita et al., (2008) hanya meneliti dua aspek yaitu perilaku belajar dan kecerdasan emosional sedangkan pada penelitian Fahrianta, Syam, \& Syahdan, (2012) menambahkan tiga aspek, yaitu kecerdasan emosional, kecerdasan spiritual terhadap pemahaman akuntansi. Perbedaan penelitian ini dengan penelitian sebelumya yaitu aspek yang diteliti pada penelitian sebelumnya pemahaman akuntansi sebagai faktor yang bisa mempengaruhi stres kuliah selain itu responden yang menjadi sampel penelitian ini berasal dari Fakultas Ekonomi Prodi Akuntansi Universitas Pasifik Morotai.

Suwardjono, (2004) menyatakan bahwa belajar di perguruan tinggi merupakan suatu pilihan srategik dalam mencapai tujuan individual seseorang. Semangat, cara belajar, dan sikap mahasiswa terhadap belajar sangat dipengaruhi oleh kesadaran akan adanya tujuan individual dan tujuan lembaga pendidikan yang jelas. Kuliah merupakan ajang untuk mengkonfirmasi pemahaman mahasiswa dalam proses belajar mandiri. Pengendalian proses belajar lebih penting daripada hasil atau nilai ujian. Kalau proses belajar dijalankan dengan baik, nilai merupakan konsekuensi logis dari proses tersebut. Belajar adalah proses perubahan perilaku akibat interaksi individu dengan lingkungan (Ali dalam Hanifah \& Abdullah, 2001) dan merupakan suatu proses usaha yang dilakukan individu untuk memperoleh suatu perubahan tingkah laku yang baru secara keseluruhan, sebagai pengalaman individu itu sendiri dalam interaksi dengan lingkunganya (Slameto, 1991 dalam Hanifah \& Abdullah, 2001).

Dampak kebiasaan belajar yang buruk bertambah berat ketika kebiasaan itu membiarkan mahasiswa dapat lolos tanpa gagal (Calhoun \& Acocella, 1995). Gagne dalam (Usman, 2017) menjelaskan bahwa hasil belajar dapat dihubungan dengan terjadinya suatu perubahan, kecakapan atau kepandaian seseorang dalam proses pertumbuhan tahap demi tahap. Hasil belajar diwujudkan dalam lima kemampuan yakni keterampilan intelektual, strategi kognitif, informasi verbal, keterampilan motorik, dan sikap. Dalam hal ini terdapat tiga dimensi belejar yaitu dimensi kognitif, dimensi afektif dan dimensi psikomotorik (Bloom, dalam Usman, 2017). Dimensi kognitif adalah kemampuan yang berhubungan dengan berfikir, mengetahui, dan memecahkan masalah. Selanjutnya dimensi ini dibagi menjadi pengetahuan komperhensif, aplikatif, sintetis, analisis dan pengetahuan evaluatif. Dimensi afektif adalah kemampuan yang berhubungan dengan sikap, nilai, minat, apresiasi. Dimensi psikomotorik yaitu kemampuan yang berhubungan dengan motorik. Atas dasar itu hakikatnya hasil belajar adalah memperoleh kemampuan kognitif melalui tiga cara yaitu: memperoleh reinforcement, classical conditioning, belajar moderen, apabila model ini mendapat reinforcement terhadap tindakanya, maka akan menjadi kebiasaan.

Kecerdasan spiritual adalah landasan yang diperlukan untuk memfungsikan kecerdasan intelektual dan kecerdasan emosional secara efektif. Kecerdasan spiritual yang baik dapat dilihat dari ketuhanan, kepercayaan, ke- pemimpinan pembelajaran, berorientasi masa depan, dan keteraturan. Oleh karena itu, mahasiswa yang memiliki kecerdasan spiritual yang tinggi akan termotivasi untuk lebih giat belajar karena mahasiswa yang memiliki kecerdasan spiritual yang tinggi, memiliki rasa ingin tahu yang tinggi, sehingga memiliki motivasi untuk selalu belajar dan memiliki kreativitas yang tinggi pula.

Akuntansi secara operasional oleh Suwardjono, (2004), didefinisikan dari dua sudut pengertian yaitu sebagai disiplin/bidang pengetahuan (studi) yang diajarkan di institusi pendidikan dan sebagai kegiatan/ proses yang dilakukan di dalam praktik. Dari sudut bidang studi, akuntansi dapat didefinisikan sebagai seperangkat pengetahuan yang mempelajari perekayasaan penyediaan jasa berupa informasi keuangan kuantitatif suatu unit organisasi dan cara penyampaian (pelaporan) informasi tersebut kepada pihak yang berkepentingan untuk dijadikan dasar dalam pengambilan keputusan ekonomi. Sedangkan akuntansi sebagai 
proses dapat didefinisikan sebagai proses pengidentifikasian, pengukuran, pencatatan, pengklasifikasian, penguraian, penggabungan, peringkasan dan penyajian data keuangan dasar yang terjadi dari kejadian-kejadian, transaksi- transaksi atau kegiatan operasi suatu unit organisasi dengan cara tertentu untuk menghasilkan informasi yang relevan bagi pihak yang berkepentingan.

Stres adalah suatu kondisi ketegangan yang mempengaruhi emosi, proses berfikir dan kondisi seseorang. Stres yang terlalu besar dapat mengancam kemampuan atau kondisi seseorang dalam menghadapi lingkungan (Handoko, 2000). Dilihat dari sudut pandang orang yang mengalami stres seseorang akan memberikan tanggapan terhadap hal-hal yang dinilai mendatangkan stres. Tanggapan orang terhadap sumber stres dapat berpengaruh pada segi psikologi dan fisiologis. Tanggapan ini disebut strain, yaitu tekanan atau ketegangan. Seseorang mahasiswa yang mengalami stres secara psikologis menderita tekanan dan ketegangan yang membuat pola pikir seseorang menjadi kacau. Dalam proses itu, hal yang dapat menyebabkan stres dan pengalaman orang yang mengalami stres akan saling berkaitan. Proses itu merupakan pengaruh timbal balik dan menciptakan usaha atau penyesuaian atau tepatnya penyeimbangan, yang terus menerus antara orang yang mengalami stres dan keadaan yang penuh stres (Umasugi et al., 2015; Anfas et al., 2018; Fahri et al., 2020)

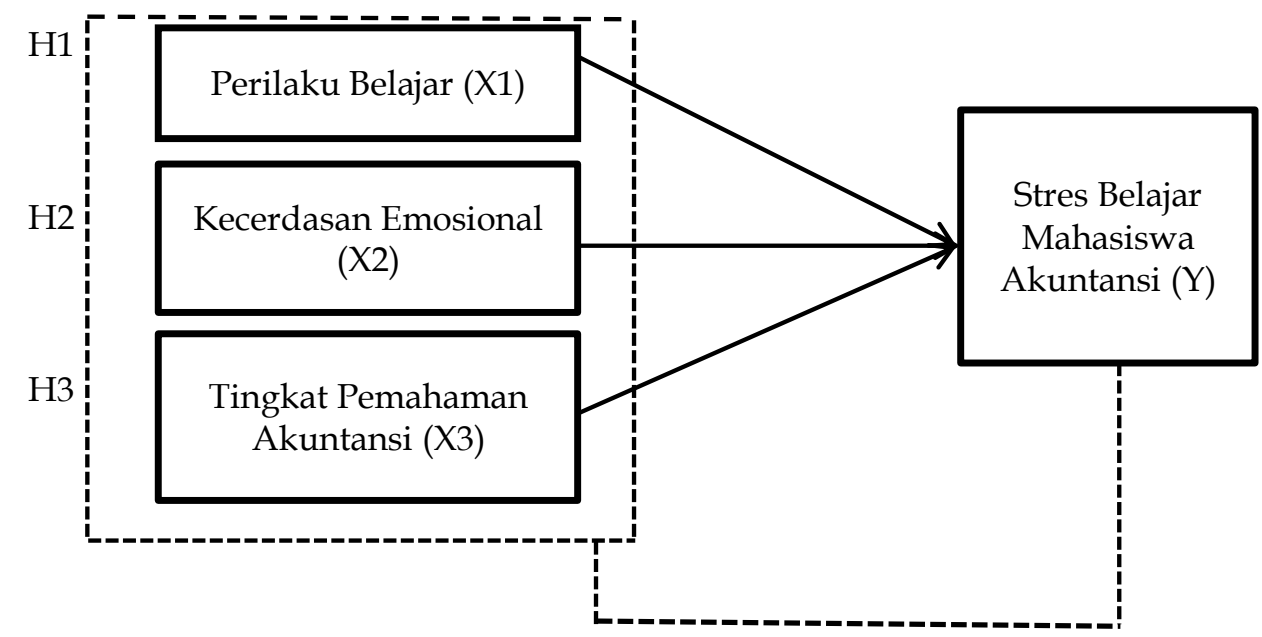

Gambar 1 Model Penelitian

Keterangan:

Parsial

Simultan.

\section{METODE PENELITIAN}

Jenis data yang digunakan dalam penelitian ini adalah data primer (kuesioner). Populasi dalam penelitian ini adalah Mahasiswa akuntansi yang ada di Fakultas Ekonomi Program Studi Akuntansi Universitas Pasifik Morotai. Metode pengumpulan sampel dalam penelitian ini menggunakan purposive sampling (Sekaran \& Bougie, 2014) dan sampel pada penelitian ini adalah mahasiswa Fakultas Ekonomi Prodi Akuntansi Universitas Pasifik Morotai sebanyak 80 orang (Sekaran, 2011). Adapun sampel yang digunakan dalam penelitian ini adalah mahasiswa akuntansi yang memenuhi kriteria sebagai mahasiswa semester lima dan tujuh, telah lulus mata kuliah auditing.

Uji validitas dan reliabilitas dalam penelitian ini menggunakan analisis faktor dan cronbach alpa. Pengujian validitas ini menggunakan pendekatan Pearson Correlation. Jika korelasi antara skor masing-masing butir pertanyaan dengan total skor mempunyai tingkat signifikansi dibawah 0.05 maka butir pertanyaan tersebut dikatakan valid, dan sebaliknya dan 
suatu kuesoner di katakan falid dan realiabel jika nilai cronbach alpa $>0.60$ (Santosa \& Ashari, 2005 dan Nurlaila \& Buamonabot, 2019). Alat analisis dalam penelitian ini menggunakan regresi linear berganda dan uji asumsi klasik seperti normalitas, multikolinieritas dan heterokedastisitas (Ghozali, 2018).

\section{HASIL DAN PEMBAHASAN}

Data penelitian dikumpulkan dengan menyebarkan 50 kuesioner kepada Mahasiswa Ekonomi Program Studi Akuntansi Universitas Pasifik Morotai. Kuesioner disebarkan sebanyak 50 kuesioner yang diantar langsung kepada responden, kuesioner ditinggalkan kemudian diambil kembali rata-rata 1 hari setelah kuesioner diserahkan. Waktu yang diperlukan untuk pengumpulan data kurang lebih selama 1 minggu dimulai dari 25 September 2019 sampai dengan 1 Oktober 2019.

Tabel 1 Hasil penyebaran Kuesioner

\begin{tabular}{lcc}
\hline \multicolumn{1}{c}{ Keterangan } & Jumlah & Presentase \\
\hline Kuesioner yang disebar & 50 & 100 \\
\hline Kuesioner yang tidak dikembalikan & 4 & 5 \\
\hline Kuesioner yang dikembalikan & 46 & 95 \\
\hline Kuesioner yang tidak dapat diolah & 10 & 12,5 \\
\hline Kuesioner yang dapat diolah & 36 & 82,5 \\
\hline \multicolumn{1}{c}{ Sumber : data primer diolah 2019 } & &
\end{tabular}

Dari seluruh responden yang disebarkan, peneliti memperoleh 46 responden atau $95 \%$ dari total kuesioner yang disebar dan hanya 36 atau 82,5\% dari total kuesioner yang disebar yang dapat dianalisa.

Tabel 2 Demografi Responden

\begin{tabular}{lcc}
\hline \multicolumn{1}{c}{ Keterangan } & $\begin{array}{c}\text { Frekuensi } \\
\text { (Orang) }\end{array}$ & Presentase \\
\hline Jenis Kelamin & 12 & 48,5 \\
1. Laki-Laki & 24 & 52,5 \\
2. Perempuan & & \\
\hline Usia & 11 & 16,7 \\
1. $\quad$ 20 tahun & 18 & 72,7 \\
2. 21-24 tahun & 7 & 10,6 \\
3. > 25 tahun & & \\
\hline Semester & 28 & 62,1 \\
1. V (Lima) & 8 & 37,9 \\
2. VIII (tujuh) & & \\
\hline
\end{tabular}

Sumber: data primer diolah 2019

Berdasarkan tabel 2 diketahui bahwa responden laki-laki berjumlah hampir sama dan didominasi oleh responden dengan usia antara 21-24 tahun $(72,7 \%)$ dengan mayoritas responden adalah semester $\mathrm{V}$ yaitu sebanyak $62,1 \%$.

Tabel 3 Hasil Uji Validitas Data

\begin{tabular}{|c|c|c|c|c|}
\hline Variabel & $\begin{array}{c}\text { Butir } \\
\text { Instrumen }\end{array}$ & r hitung & $\begin{array}{c}\text { Cronbach's } \\
\text { alpa }\end{array}$ & Keterangan \\
\hline$(\mathrm{Y})$ & $\mathrm{Y} \_1$ & 0,479 & 0,835 & Valid dan \\
\hline
\end{tabular}




\begin{tabular}{|c|c|c|c|c|}
\hline & $\begin{array}{l}\text { Y_2 } \\
\text { Y_3 } \\
\text { Y_4 } \\
\text { Y_5 } \\
\text { Y_6 } \\
\text { Y_7 } \\
\text { Y_8 } \\
\text { Y_9 }\end{array}$ & $\begin{array}{l}0,518 \\
0,747 \\
0,693 \\
0,690 \\
0,693 \\
0,771 \\
0,776 \\
0,657\end{array}$ & & Reliabel \\
\hline$(\mathrm{X} 1)$ & $\begin{array}{l}\mathrm{X} 1 \_1 \\
\mathrm{X} 1 \_2 \\
\mathrm{X} 1 \_3 \\
\mathrm{X} 1 \_4 \\
\mathrm{X} 1 \_5 \\
\mathrm{X} 1 \_6 \\
\mathrm{X} 1 \_7\end{array}$ & $\begin{array}{l}0,621 \\
0,705 \\
0,740 \\
0,706 \\
0,481 \\
0,551 \\
0,689 \\
\end{array}$ & 0,759 & $\begin{array}{c}\text { Valid dan } \\
\text { Reliabel }\end{array}$ \\
\hline$(\mathrm{X} 2)$ & $\begin{array}{l}\mathrm{X} 2 \_1 \\
\mathrm{X} 2 \_2 \\
\mathrm{X} 2 \_3 \\
\mathrm{X} 2 \_4 \\
\mathrm{X} 2 \_5 \\
\mathrm{X} 2 \_6 \\
\mathrm{X} 2 \_7 \\
\mathrm{X} 2 \_8\end{array}$ & $\begin{array}{l}0,642 \\
0,625 \\
0,783 \\
0,483 \\
0,564 \\
0,489 \\
0,547 \\
0,425\end{array}$ & 0,695 & $\begin{array}{c}\text { Valid dan } \\
\text { Reliabel }\end{array}$ \\
\hline (X3) & $\begin{array}{l}\text { X3_1 } \\
\text { X3_2 } \\
\text { X3_3 } \\
\text { X3_4 } \\
\text { X3_5 } \\
\text { X3_6 } \\
\text { X3_7 } \\
\text { X3_8 } \\
\text { X3_9 }\end{array}$ & $\begin{array}{l}0,780 \\
0,663 \\
0,827 \\
0,796 \\
0,589 \\
0,539 \\
0,540 \\
0,525 \\
0,558 \\
\end{array}$ & 0,831 & $\begin{array}{c}\text { Valid dan } \\
\text { Reliabel }\end{array}$ \\
\hline
\end{tabular}

Sumber: data primer diolah tahun 2019

Untuk memastikan apakah model regresi telah terbebas dari penyimpangan asumsi klasik, maka dilakukan uji asumsi klasik yang terdiri dari uji multikolenieritas, uji normalitas, dan uji heteroskedastisitas.

Tabel 4 Hasil Uji Multikolonieritas

\begin{tabular}{ccc}
\hline \multirow{2}{*}{ Variabel } & \multicolumn{2}{c}{ Collinearity Statistics } \\
\cline { 2 - 3 } & Tolerance & VIF \\
\hline $\mathrm{X} 1$ & .481 & 2.077 \\
\hline $\mathrm{X} 2$ & .596 & 1.677 \\
\hline $\mathrm{X} 3$ & .523 & 1.913 \\
\hline \multicolumn{2}{c}{ Sumber: data primer diolah 2019 }
\end{tabular}

Dari hasil tabel di atas, terlihat bahwa dari variabel independen dengan nilai VIF tidak lebih dari 10 dan nilai Tolerance tidak kurang dari 0,1 sehingga dapat disimpulkan dalam model regresi ini tidak ada masalah multikolinieritas. 


\section{Normal P-P Plot of Regression Standardized Residual}

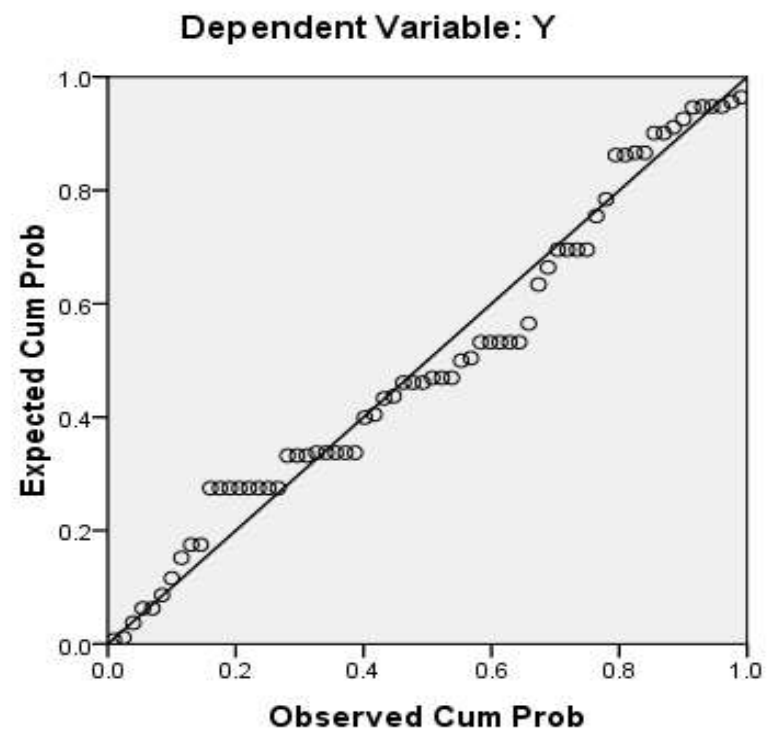

Gambar 1 Hasil Uji Normalitas

Sumber: data primer diolah 2019

Pada gambar grafik P-P Plot menunjukkan bahwa data menyebar di sekitar garis diagonal dan mengikuti arah garis diagonal. Oleh karena itu, grafik P-P Plot menunjukkan bahwa data terdistribusi normal. Berdasarkan grafik scatterplot di atas tampak bahwa sebaran data tidak membentuk pola yang jelas, titik-titik data menyebar di atas dan di bawah angka 0 pada sumbu Y. Hal ini mengindikasikan bahwa tidak terjadi heteroskedastisitas dalam model regresi.

Scatterplot

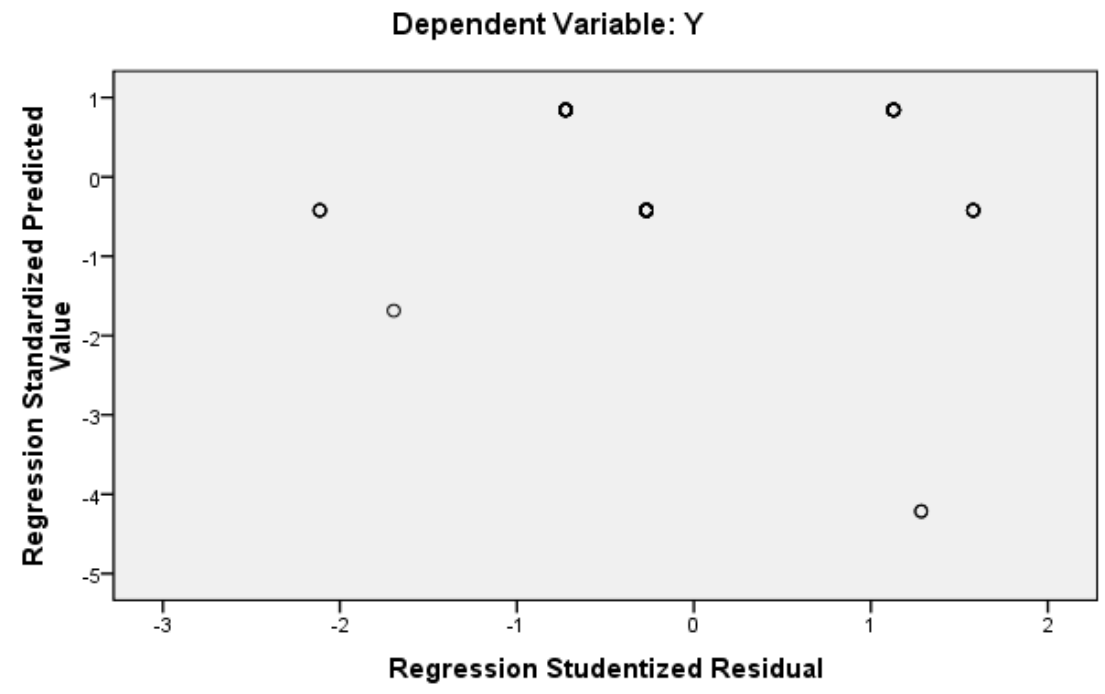

Gambar 2 Hasil Uji Heterokedastisitas

Sumber: data primer diolah 2019 
Berdasarkan tabel 5 skor responden yang menjawab pertanyaan pada variabel perilaku belajar cenderung memilih setuju. Hal ini bisa dilihat dari nilai rerata yang sebagian besar lebih besar dari 3 (tiga) dan untuk nilai standar deviasi memiliki penyimpangan yang masih dalam tahapan wajar.

Tabel 5 Deskripsi Variabel Perilaku Belajar (X1)

\begin{tabular}{cccccccccc}
\hline Skor & SS & S & N & TS & STS & Mean & $\begin{array}{c}\text { Standar } \\
\text { Deviasi }\end{array}$ & Maks & Min \\
\hline $\mathrm{X} 1 \_1$ & 10 & 13 & 11 & 1 & 1 & 3.7576 & 0.78565 & 5,00 & 1,00 \\
\hline $\mathrm{X} 1 \_2$ & 5 & 10 & 9 & 11 & 1 & 3.4091 & 0.91108 & 5,00 & 1,00 \\
\hline $\mathrm{X} 1 \_3$ & 7 & 12 & 11 & 6 & 0 & 3.6061 & 0.80151 & 5,00 & 2,00 \\
\hline $\mathrm{X} 1 \_4$ & 7 & 11 & 15 & 3 & 0 & 3.7879 & 0.69093 & 5,00 & 2,00 \\
\hline $\mathrm{X} 1 \_5$ & 8 & 11 & 11 & 6 & 0 & 3.6212 & 0.81835 & 5,00 & 2,00 \\
\hline $\mathrm{X} 1 \_6$ & 9 & 12 & 13 & 2 & 0 & 3.8788 & 0.66830 & 5,00 & 2,00 \\
\hline $\mathrm{X} 1 \_7$ & 13 & 16 & 6 & 1 & 0 & 3.9242 & 0.70842 & 5,00 & 2,00 \\
\hline \multicolumn{7}{l}{ Sumber: data primer diolah tahun 2019 }
\end{tabular}

Berdasarkan tabel 6 skor responden yang menjawab pertanyaan pada variabel kecerdasan emosional cenderung memilih sangat setuju. Hal ini bisa dilihat dari nilai rerata yang sebagian besar lebih besar dari 4 (tiga) dan untuk nilai standar deviasi memiliki penyimpangan yang masih dalam tahapan wajar.

Tabel 6 Deskripsi Variabel Kecerdasan Emosional (X2)

\begin{tabular}{cccccccccc}
\hline Skor & SS & S & N & TS & STS & Mean & $\begin{array}{c}\text { Standar } \\
\text { Deviasi }\end{array}$ & Maks & Min \\
\hline X2_1 & 19 & 13 & 2 & 0 & 2 & 4.3182 & 0.80688 & 5,00 & 1,00 \\
\hline X2_2 & 13 & 19 & 1 & 1 & 2 & 4.2121 & 0.81364 & 5,00 & 1,00 \\
\hline X2_3 & 17 & 13 & 4 & 0 & 1 & 4.2576 & 0.82854 & 5,00 & 1,00 \\
\hline X2_4 & 17 & 16 & 13 & 0 & 0 & 4.0606 & 0.67662 & 5,00 & 3,00 \\
\hline X2_5 & 7 & 19 & 10 & 0 & 0 & 3.8030 & 0.61318 & 5,00 & 3,00 \\
\hline X2_6 & 13 & 15 & 7 & 0 & 1 & 4.0455 & 0.66638 & 5,00 & 1,00 \\
\hline X2_7 & 10 & 19 & 7 & 0 & 0 & 4.0455 & 0.50935 & 5,00 & 3,00 \\
\hline X2_8 & 10 & 9 & 9 & 8 & 0 & 3.8333 & 0.93781 & 5,00 & 2,00 \\
\hline \multicolumn{7}{c}{ Sumber: data primer diolah tahun 2019} & & &
\end{tabular}

Berdasarkan tabel 7 skor responden yang menjawab pertanyaan pada variabel tingkat pemahaman cenderung memilih sangat setuju. Hal ini bisa dilihat dari nilai rerata yang sebagian besar lebih besar dari 4 (tiga) dan untuk nilai standar deviasi memiliki penyimpangan yang masih dalam tahapan wajar.

Tabel 7 Deskripsi Variabel Tingkat Pemahaman Akuntansi (X3)

\begin{tabular}{cccccccccc}
\hline Skor & SS & S & N & TS & STS & Mean & $\begin{array}{c}\text { Standar } \\
\text { Deviasi }\end{array}$ & Maks & Min \\
\hline X3_1 & 4 & 14 & 16 & 3 & 3 & 3.2576 & 0.93333 & 5,00 & 1,00 \\
\hline X3_2 & 8 & 11 & 11 & 6 & 0 & 3.6212 & 0.81835 & 5,00 & 2,00 \\
\hline X3_3 & 6 & 12 & 17 & 0 & 0 & 3.3333 & 0.90014 & 5,00 & 1,00 \\
\hline X3_4 & 4 & 13 & 16 & 2 & 1 & 3.2576 & 0.88249 & 5,00 & 1,00 \\
\hline X3_5 & 3 & 17 & 10 & 4 & 2 & 3.3030 & 0.87653 & 5,00 & 1,00 \\
\hline X3_6 & 13 & 19 & 1 & 1 & 2 & 4.2121 & 0.81364 & 5,00 & 1,00 \\
\hline
\end{tabular}




\begin{tabular}{cccccccccc}
\hline Skor & SS & S & N & TS & STS & Mean & $\begin{array}{c}\text { Standar } \\
\text { Deviasi }\end{array}$ & Maks & Min \\
\hline X3_7 & 17 & 13 & 4 & 0 & 2 & 4.2576 & 0.82854 & 5,00 & 1,00 \\
\hline X3_8 & 3 & 10 & 19 & 4 & 0 & 3.6364 & 0.67108 & 5,00 & 2,00 \\
\hline X3_9 & 7 & 18 & 5 & 5 & 1 & 3.6818 & 0.82572 & 5,00 & 1,00 \\
\hline \multicolumn{8}{l}{ Sumber Data Primer Diolah 2019 }
\end{tabular}

Berdasarkan tabel 8 skor responden yang menjawab pertanyaan pada variabel stres belajar mahasiswa akuntansi cenderung memilih sangat setuju. Hal ini bisa dilihat dari nilai rerata yang sebagian besar lebih besar dari 4 (tiga) dan untuk nilai standar deviasi memiliki penyimpangan yang masih dalam tahapan wajar.

Tabel 8 Deskripsi Variabel Stres Belajar Mahasiswa Akuntansi (Y)

\begin{tabular}{|c|c|c|c|c|c|c|c|c|c|}
\hline Skor & SS & $S$ & $\mathbf{N}$ & TS & STS & Mean & $\begin{array}{l}\text { Standar } \\
\text { Deviasi }\end{array}$ & Maks & Min \\
\hline Y_1 & 10 & 13 & 10 & 3 & 0 & 3.7576 & 0.76582 & 5,00 & 2,00 \\
\hline $\mathrm{Y} \_2$ & 12 & 10 & 10 & 4 & 0 & 3.8333 & 0.93781 & 5,00 & 2,00 \\
\hline Y_3 & 17 & 14 & 5 & 0 & 0 & 4.3333 & 0.61603 & 5,00 & 3,00 \\
\hline Y_4 & 12 & 19 & 4 & 0 & 1 & 4.2273 & 0.69715 & 5,00 & 1,00 \\
\hline Y_5 & 10 & 20 & 6 & 0 & 0 & 4.2121 & 0.59524 & 5,00 & 3,00 \\
\hline Y_6 & 19 & 12 & 4 & 1 & 0 & 4.3485 & 0.66777 & 5,00 & 2,00 \\
\hline Y_7 & 17 & 16 & 2 & 1 & 0 & 4.0455 & 0.71105 & 5,00 & 2,00 \\
\hline Y_8 & 14 & 12 & 8 & 1 & 1 & 4.1667 & 0.81492 & 5,00 & 1,00 \\
\hline Y_9 & 13 & 12 & 8 & 3 & 0 & 4.1364 & 0.80166 & 5,00 & 2,00 \\
\hline
\end{tabular}

Tabel 9 Hasil Uji Regresi Berganda

\begin{tabular}{lcccc}
\hline \multirow{2}{*}{ Variabel Penelitian } & \multicolumn{4}{c}{ Regresi Berganda } \\
\cline { 2 - 5 } & Koef. Regresi ( $\boldsymbol{\beta})$ & SE & t-hitung & Sig. t (P) \\
\hline Konstanta & 1.184 & 0.477 & 2.485 & 0.016 \\
Perilaku Belajar (X1) & 0.287 & 0.140 & 2.058 & 0.044 \\
Kecerdasan Emosional (X2) & 0.565 & 0.147 & 7.896 & 0.000 \\
Pemahaman Akuntansi (X3) & 0.417 & 0.122 & 2.482 & 0.041 \\
\hline Multiple R & 0.629 & & & \\
R Square & 0.396 & & & \\
Adj. R Square & 0.367 & & & \\
F & 13.554 & &
\end{tabular}

Sumber: data primer diolah tahun 2019

Berdasarkan data di atas hasil analisis regresi berganda untuk membuktikan pengaruh variabel perilaku belajar $\left(\mathrm{X}_{1}\right)$, kecerdasan emosional $\left(\mathrm{X}_{2}\right)$, tingkat pemahaman akuntansi $\left(\mathrm{X}_{3}\right)$ terhadap stres belajar mahasiswa akuntansi $(Y)$ dengan asumsi bahwa variabel lain dianggap konstan, maka dapat dikatakan bahwa terdapat pengaruh yang signifikan positif kuat pada variabel perilaku belajar $\left(\mathrm{X}_{1}\right)$, kecerdasan emosional $\left(\mathrm{X}_{2}\right)$, tingkat pemahaman akuntansi $\left(\mathrm{X}_{3}\right)$. Hal ini ditunjukkan dengan koefisien regresi berganda (Multiple $R$ ) yang diperoleh sebesar 0.629 atau $62.9 \%$. dengan demikian koefisien korelasi menunjukan tingkat ketepatan garis regresi yang dibentuk dari variabel dependen (Y) stres belajar mahasiswa akuntansi dijelaskan oleh variabel independen variabel perilaku belajar $\left(X_{1}\right)$, kecerdasan emosional $\left(X_{2}\right)$, tingkat pemahaman akuntansi $\left(\mathrm{X}_{3}\right)$ adalah positif signifikan. Penyesuaian terhadap koefisien determinasi (adjusted $R$ Square) yang diperoleh sebesar 0.367 atau 36.7\%. dengan demikian dapat dikatakan bahwa variabel independen perilaku belajar $\left(\mathrm{X}_{1}\right)$, kecerdasan emosional $\left(\mathrm{X}_{2}\right)$, 
tingkat pemahaman akuntansi $\left(\mathrm{X}_{3}\right)$ perlu menambahkan variabel lain yang berhubungan dengan stres belajar mahasiswa akuntansi $(Y)$. hasil penelitian ini sesuai dengan penelitian Marita et al., (2008) dan Fahrianta et al., (2012) bahwa perilaku belajar, kecerdasan emosional dan tingkat pemahaman akuntansi signifikan terhadap stres belajar mahasiswa akuntansi.

\section{SIMPULAN}

Penelitian ini bertujuan untuk menguji pengaruh Perilaku belajar terhadap stres belajar mahasiswa akuntansi. Pengaruh kecerdasan emosional terhadap belajar kulia mahasiswa akuntansi. Pengaruh pemahaman akuntansi terhadap stres belajar mahasiswa akuntansi. Disamping itu juga untuk menguji pengaruh perilaku belajar, kecerdasan emosional dan tingkat pemahaman akuntansi terhadap stres belajar mahasiswa akuntansi. Berdasarkan hasil dan pembahasan di atas, maka terdapat beberapa kesimpulan, yakni pertama, hasil pengujian variabel perilaku belajar secara parsial berpengaruh positif signifikan terhadap stres belajar mahasiswa akuntansi. Kedua, penelitian ini membuktikan bahwa secara parsial kecerdasan emosional berpengaruh positif signifikan terhadap stres belajar mahasiswa akuntansi. Ketiga, penelitian ini membuktikan bahwa secara parsial pemahaman akuntansi berpengaruh positif signifikan terhadap stres belajar mahasiswa akuntansi. Keempat, hasil pengujian dengan regresi berganda menunjukkan bahwa secara bersama-sama perilaku belajar, kecerdasan emosional dan tingkat pemahaman akuntansi berpengaruh terhadap stres belajar mahasiswa akuntansi.

\section{DAFTAR PUSTAKA}

Anfas, A., Buamonabot, I., Umasugi, M., \& Sudarwo, R. (2018). Pengukuran Tingkat Stres Mahasiswa Berdasarkan Gender: Aplikasi Impotance Performace Analysis. Jurnal Pendidikan Terbuka Dan Jarak Jauh, 19(1), 38-51. https://doi.org/10.33830/ptij.v19i1.315.2018

Aziza, N., \& RM, R. M. (2006). Pengaruh Kecerdasan Emosional Terhadap Tingkat Pemahaman Akuntansi, Kepercayaan Diri Sebagai Variabel Pemoderasi. Simposium Nasional Akuntansi 9 Padang, 1-49.

Calhoun, J. F., \& Acocella, J. R. (1995). Psikologi Tentang Penyesuaian dan Hubungan Kemanusiaan. Semarang: IKIP Semarang Press.

Crampton, S. M., Hodge, J. W., Mishra, J. M., \& Price, S. (1995). Stress and stress management. Society for the Advancement of Management, 60(3).

Fahri, J., Syahrain, R., \& Buamonabot, I. (2020). Developing Measurement Indicators for Stress Academic Models at Higher Education Institutions: An Importance Performance Analysis Approach. 5th International Conference on Food, Agriculture and Natural Resources (FANRes 2019), 404-407. https:/ / doi.org/https:// dx.doi.org/10.2991/aer.k.200325.081

Fahrianta, R. Y., Syam, A. Y., \& Syahdan, S. A. (2012). Pengaruh kecerdasan Emosional dan Kecerdasan Spiritual Mahasiswa Akuntansi Terhadap Tingkat Pemahaman Akuntansi. Jurnal Ilmu-Ilmu Sosial, 4(2).

Ghozali, I. (2018). Aplikasi analisis multivariete dengan program IBM SPSS 23.

Hanifah, \& Abdullah, S. (2001). Pengaruh Perilaku Belajar Terhadap Prestasi Akademik Mahasiswa Akuntansi. Media Riset Akuntansi, Auditing Dan Informasi, 1(3), 63-86. https://doi.org/10.25105/mraai.v1i3.1767

Kariv, D., \& Heiman, T. (2005). Task-oriented versus emotion-oriented coping strategies: The case of college students. College Student Journal, 39(1), 72-85.

Marita, Suryaningsum, S., \& Shaalih, H. N. (2008). Kajian Empiris Atas Perilaku Belajar Dan Kecerdasan Emosional Dalam Mempengaruhi Stres Kuliah Mahasiswa Akuntansi. Simposium Nasional Akuntansi XI. Pontianak.

Nurlaila, N., \& Buamonabot, I. (2019). Pengaruh Budaya Organisasi terhadap Komitmen 
Organisasi Pegawai Kantor Pelabuhan Perikanan Nusantara (PPN) Ternate. Mala'bi Jurnal Manajemen Ekonomi STIE Yapman Majene, 2(1), 76-90. Retrieved from http://ejournal.stieyapman.ac.id/index.php/jme/article/view/45

Rachmi, F. (2011). Pengaruh Kecerdasan Emosional, Kecerdasan Spiritual, Dan Perilaku Belajar Terhadap Tingkat Pemahaman Akuntansi (Studi Empiris pada Mahasiswa Akuntansi Universitas Diponegoro Semarang dan Universitas Gajah Mada Yogyakarta). Universitas Diponegoro.

Risharliea, T. (2011). Kajian Empiris Atas Perilaku Belajar, Kecerdasan ntelektual, Kecerdasan Emosional dan Kecerdasan Spiritual dalamMempengaruhi Stres Kuliah Mahasiswa Akuntansi. Universitas Islam Indonesia, Yogyakarta.

Santosa, P. B., \& Ashari. (2005). Analisis statistik dengan Microsoft Excel dan SPSS. Yogyakarta: Andi.

Sekaran, U., \& Bougie, R. (2014). Research Method For Business. In Library of Congress. https://doi.org/10.1007/978-94-007-0753-5_102084

Suwardjono. (2004). Perilaku Belajar di Perguruan Tinggi. Jurnal Akuntansi Dan Manajemen STIE YKPN.

Umasugi, M., Buamonabot, I., \& Anfas, A. (2015). Pengukuran Tingkat Stres Mahasiswa Yang Belum dan Sudah Bekerja: Sebuah Studi Deskriptif. Manajemen Sinergi, 3(1), 71-83. Usman, M. U. (2017). Menjadi Guru Profesional (29th ed.). Bandung: PT. Remaja Rosdakarya. 